
and Aromatic Plants

An International Journal ISSN: 2619-9645 | e-ISSN: 2667-5722

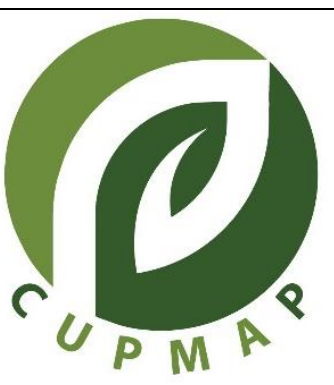

\title{
Ethnobotanical Survey of Some Plants Used in Tessala Region, Algeria
}

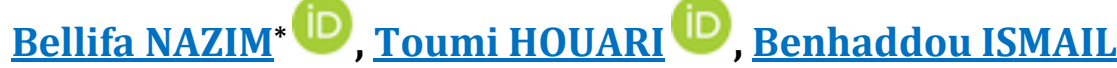 \\ Department of Pharmacy, Pharmacognosy Laboratory, Faculty of Medecine, University of Djilali Liabes, \\ Postal code 22000, City Sidi Bel Abbes-Algeria \\ *Corresponding author : nazim.bellifa@univ-sba.dz
}

https://doi.org/10.38093/cupmap.652708

Received : 29/11/2019 Accepted : 05/04/2020

\begin{abstract}
The area of Tessala is home to very diverse vegetation between forest and steppe species more than 1000 meters high, there are aromatic plants thus participating in the economy of the region this wealth is not exploited where the interest of our study in the framework of the valorization of the natural resources by an inventory of the flora and an ethnobotanical investigation using a standardized survey dedicated to the tradipraticiens. Subsequently, this work was complemented by the identification of field samples at the Botanical Laboratory of the faculty of medicine using flora and herbaria available to translate this traditional folk knowledge into scientific knowledge. Thus, the scientific knowledge of the medicinal flora of the region studied allowed us to gather the maximum of information concerning the therapeutic uses practiced by the local population. As a result of the floristic inventory a total of 80 medicinal plants, distributed in 50 genera, were collected and identified. Plant family with the highest medicinal plants in the study area used for various diseases treatment was Lamiaceae. The survey revealed more than 40 species used for several pathologies ranging from simple dermatological disease to hypertension and diabetes while Pistacia, Marrubium, and Myrtus were the most frequently utilized plant, However, to save medicinal plants from further loss, involving local communities in the cultivation of the most utilized medicinal plants is recommended.
\end{abstract}

Key Words: Aromatic plants, Ethnobotanical study, Flora, Inventory, Medicinal plants, Traditional, Valorization

(c) CUPMAP. All rights reserved.

\section{Introduction}

Nature is a huge deposit of active molecules of plant origin, and the resources of the flora are far from being fully inventoried. Around the world, we continue today to look for plants that can be used as a basis for new treatments. Today, the search for new drug molecules of natural origin continues to be an urgent necessity and is based on the quality of medicinal plants and on ethnobotanical studies that make it possible to make inventories of plants of a region, by determining their quality. by phytochemical and pharmacological studies (Guedira and Goetz, 2008). In Algeria species of spontaneous flora constitutes a significant part of local genetic resources with pastoral, forage, food, aromatic and/or medicinal value (Adrar, 2015).

Therefore, to make an appreciable contribution to the knowledge of this plant biodiversity and development of the natural 
resources of Tessala, Western Algeria it has been considered useful to do a floristic and ethnobotanical study. In addition to the programs of some international organizations such as (IUCN), which aims to promote the conservation of biodiversity and the sustainable use of natural resources in North Africa and the involvement of local communities in the conservation of biodiversity, our laboratory is trying to carry out floristic, phytochemical and ethnobotanical research of medicinal plants in different regions of Sidi bel abbes, this work also aims to support the rural poor by strengthening their identity, their sources of income and their food security by promotion of the use of neglected species. (Belkhadar, 1997).

\section{Material and Method}

\subsection{Ethnobotanical data collection and analysis}

First a floristic inventory, then an ethnobotanical survey was carried out in the region of Tessala near traditional healers based on a questionnaire developed and standardized according to the pharmalex platform to draw up a list of plants with the scientific name, the family, vernacular name, usage and method of preparation.

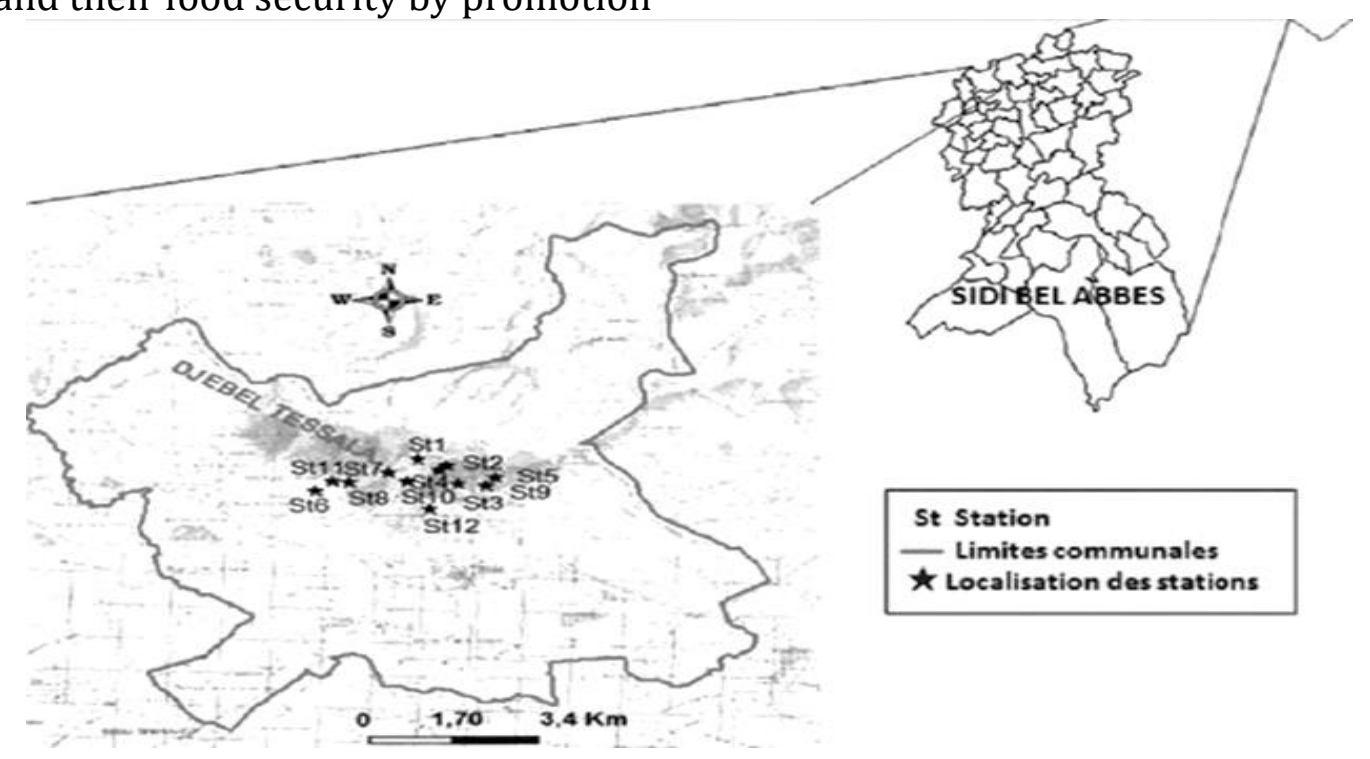

Figure 1. Presentation of the area of study

The survey carried out concerned the commune of Tessala the location of the different survey environments was identified by stratified sampling techniques. These techniques seemed appropriate for conducting ethnobotanical surveys varied from one area to another in this study. We sought to delimit and explore the maximum areas of the region. For this, two field campaigns were planned during the years 2018 and 2019. And using 40 questionnaire sheets that were prepared and rectified, we carried out ethnobotanical surveys in the region studied (Figure 1) to have as much information as possible about the use of medicinal plants by the local population. For the identification and determination of species, we used the new flora of Algeria and the southern desert regions (Paul Ozenda, 1991) and the flora of North Africa (Quezel and Santa, 1962) and the flora of the laboratory of the pharmacognosy of the faculty of medicine of Sidi bel abbes. Also, an herbarium has been made and stored in the Tlemcen pharmacognosy laboratory, an electronic version of which is available.

\subsection{Presentation of the area study}

The mountains of Tessala are located in the north of western Algeria, and more precisely 
north of Sidi Bel Abbés (Figure 1). Composed of sedimentary rocks, they form an elongated massif, which belongs to the Tellian Atlas. They culminate at Djebel Tessala which reaches $1061 \mathrm{~m}$ of altitude. Most soils (Benyahia et al., 2001) belong to the class of raw mineral soils: lithosols and regosols of the French classification. There are also some rendzines Calcium brown soils are rare, the climate is the Mediterranean. Rainfall is concentrated in autumn and winter, while the drought period is 6 months, from April to September (Ferka-Zazou, 2006).

Table1. List of plants identified in the ethnobotanical survey

\begin{tabular}{|c|c|c|c|}
\hline Scientific name & $\begin{array}{l}\text { Vernacular } \\
\text { name }\end{array}$ & Traditional use & Preparation method \\
\hline Ajuga-iva & chendgoura & Diabetes & Decoction \\
\hline Ampelodessma mauritanicus & Diss & Digestion & Decoction \\
\hline Aristidi pungens & retam & Multiple uses & Powdre aerial part \\
\hline Arthrophytum scoparium & Remeth & Hepatitis & Decoction \\
\hline Artemisia herba-alba & Chih & Emmenagogue & Decoction \\
\hline Asparagus acutifollus & Sekoum & Gout disease & Drop fruit \\
\hline Asphodelus microcarpus & Belouz & Cold snap & Tubercule comestibl \\
\hline Atractylis gummifera & Addad & Dermatological affaction & Root \\
\hline Atriplex halimus & Guettaf & Emmenagogue & Decoction \\
\hline Rhamnus alaternus & meliles & Ictere, jaundice & Bark decoction \\
\hline Bellis annua & Hallala & Furunculosis & Cataplasm \\
\hline Bourrago officinalis & Lessan elferd & Diuretic & Flower \\
\hline Chamerops humilis & Gaze & Digestive & Fruit comestibl \\
\hline Cistus & tanghoust & Rheumatism & Maceration \\
\hline Calycotome spinosa & Guendoul & Cardiovascular & Infused flower \\
\hline \multicolumn{4}{|l|}{ Coronilla valentina } \\
\hline Daphne gnidium & Lazez & Sinusitis & Maceration,cataplasm \\
\hline Euphorbia helioscopia & Tabera & Vomitingt, aphthae & Roots \\
\hline Globularia alypum & Tesselra & Constipation & Infusion \\
\hline Kundmaninia & Zeyata & Diabetes Obesity & Root \\
\hline Marubium album & Merioua & Urinary infection & Decoction \\
\hline Myrtus communis & Rayhan & Antiseptic & Fumigation \\
\hline Lavandula stoechas & Halhal & Dyslipidemia & Infusion \\
\hline Olea europea & Zitoun & Hypertension and diabetes & Dried leaves \\
\hline Phillyrea angustifolia & Ktem & Hair & Tinctorial \\
\hline Pinus halepensis & Zenin & Cough & Fumigation, oil \\
\hline Pistachia lentiscus & Darou & Hypertension and diabetes & Oil, decoction, dried leaves \\
\hline Plantago longopus & Lalema & Kidney calcul & Infusion \\
\hline Quercus coccifera & Belout & Diarrhea, hernia & Decoction Bark \\
\hline Rosmarinus officinalis & Iklil el jabel & $\begin{array}{l}\text { Hepatoprotective } \\
\text { Painful menstruation }\end{array}$ & Infusion \\
\hline Ruta chalepensis & Fidjela & Emmenagogue & Leaves \\
\hline Salvia verbenaca & keyata & Healing & Leaf application \\
\hline Salvia argentea & Ferachet e neda & Healing & Fresh leaf \\
\hline Saxifragas globulifera & Fetat el hejer & Calculation of the kidneys & Decoction \\
\hline Scolymus hispanica & Guernina & pains & Powder \\
\hline Tetraclinis articulata & Araar & Antiseptic & Fumigation \\
\hline Thapsia garganica & Deryas & Rheumatism & Bulbe maceration with olive oil \\
\hline Teucrium polium & Latay el khela & Dyslipidemia & Maceration \\
\hline Thymus vulgaris & Zaater & Cough, flu, allergy & $\begin{array}{l}\text { Infusion, decoction, } \\
\text { cataplasm }\end{array}$ \\
\hline Thymelaea hirsuta & Metnan & Pain & Decoction, infusion \\
\hline
\end{tabular}




\section{Results and Discussion}

The floristic inventory has collected more than 50 genera and 80 species distributed throughout the study area, while the survey allowed for a table with more than 40 species to better understand the relationships between species and types of diseases, we initially limited ourselves to medicinal plants with a relatively high frequency of use. In the Tell there is mainly the Aleppo Pine which is well adapted to the region, next to it there are other secondary species: The Holm and kermes, Thuya, Juniperus.

The undergrowth includes various Cistus Pistacia , Filaria, Olea europea, Arbutus, Cysts, Rosemary, Dwarf Palm, Alfa, Diss (Ampelodesmos tenax), next to it The Alfa dominates the rocky steppe, in stony soils with shallow soils. Associated with alfa, we find a range of perennial or annual plants: Bromus squarrosus, Bromus bordaceas, Thymus ciliatus, Asphodelus, Astragalus, Rosmarinus, Cistus, Libanotus,
Echinariacapitala, Avena alba, Galium, Alfa is exploited by herds of sedentary or seminomadic inhabitants of the region. And a steppe to Artemesia herba alba: It occupies not only the previous areas but the southern area of the region. The white sagebrush, which is frequently mixed with the esparto grass (Lygeum spartum) and the whitish plantain (Plantago albicans), is continuous and homogeneous for tens of kilometers and only disappears in the dahyas (small closed depressions, sometimes filled with water, during heavy rains) or dominate graminaceous vegetation, including sedge bromus divided. (Quezel and Santa, 1962)

The ethnobotanical survey has made it possible to draw up a table with more than 40 species described below with several pathologies treated from a simple mycosis to kidney stones and hepatitis. The Lamiaceae family is largely predominant with more than 8 genera followed by the family. Asteraceae Apiaceae, Fabaceae, Oleaceae.

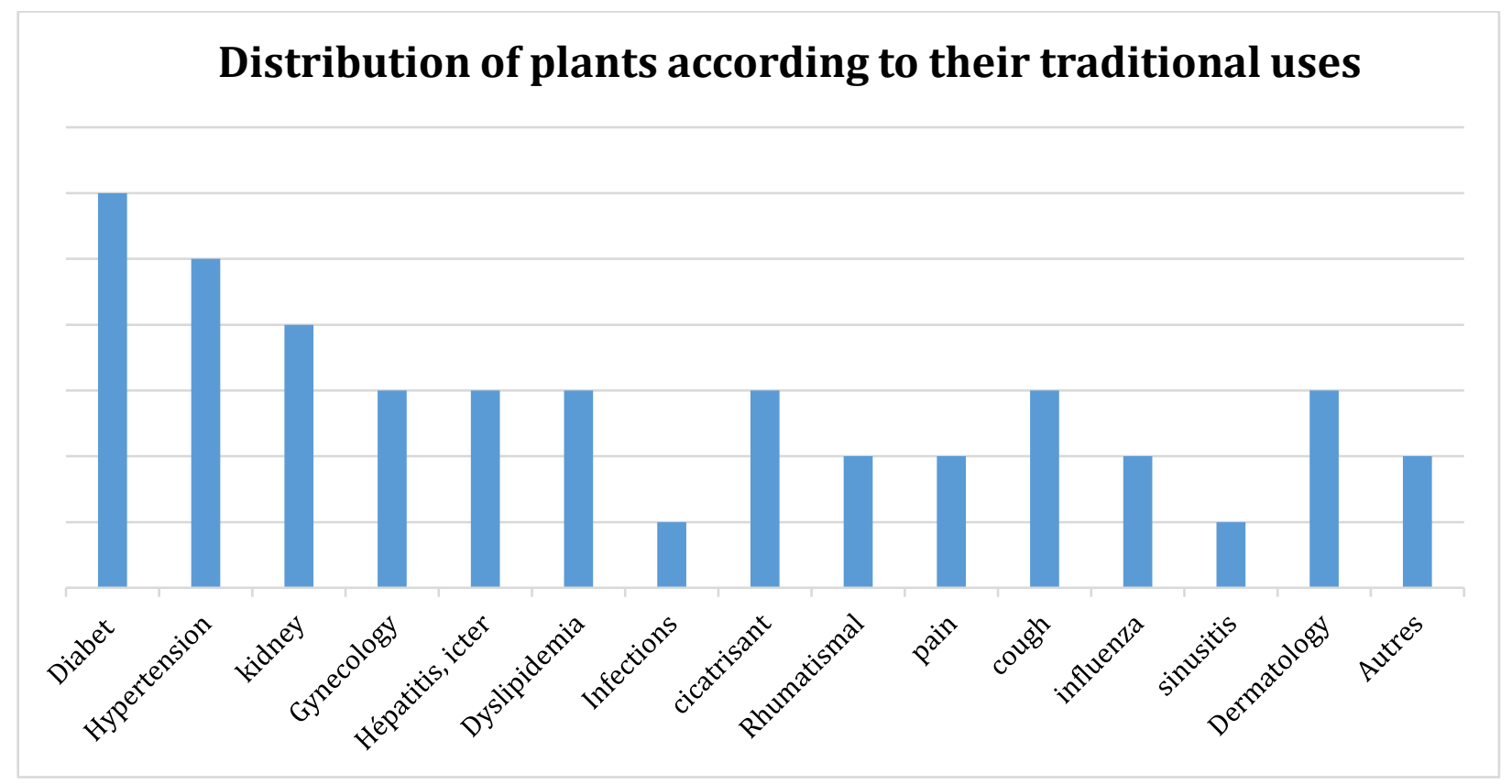

Figure 2. Distribution of plants according to their traditional uses

For the preparation method, the decoction is predominant but we also note poultices fumigations, for the traditional use diabetes is very concerned then kidney stones with 4 recommended plants, then dyslipidemia and cardiovascular diseases and finally the other 
indications whose hepatitis, gastric disorders, gyneco-obstetrics, rheumatism, flu, sinusitis, dermatological disorders.

The most utilized species in the treatment of respiratory diseases (Table 1 ), we note the massive use of Myrtus for its phytotherapeutic properties particularly flu, colds, coughs, and lung diseases. It is also recognized as a plant par excellence of the diseases of winter that is to say the cooling of all kinds. We also note the use of Slavia argentea and its excellent qualities especially for its ability to heal wounds and burns, Marrubium album in the treatment of urinary infections against women and Ruta in the preparation of a meal for women suffering from amenorrhea which is accompanied by hot buffets, Daphne gnidium and Phillyrea angustifolia to prepare a tincture in cases of hair loss giving good results. These results confirm those of Belkhadar, 1997; Dif et al., 2015 and Khitri and Lardjam, 2018), notably in Morocco Hseini and Kahouadji and al (Tahri et al., 2012).

\section{Conclusion}

The region of Tessala with its abundant and varied flora is a real reserve with several species with great therapeutic potential and unveiled through this ethnobotanical survey, the species Phillyrea angustifolia L. is considered the preferred plant for the hair with the Daphne. It has also been noticed that Artemisia is a medicinal plant very much appreciated by women, because of its emmenagogues properties. The species Marrubium album L. is well known in the region studied for its effective action in the therapy of the urinary tract, in the end, the genus Salvia used for the preparation of poultice for its healing power very famous.

These species have a comparative advantage over other crops in adapting to environmental conditions, medicinal value, and resistance to adverse climatic conditions. Besides, their safeguarding is important for the protection of local identities, cultural traditions, and local know-how, for the promotion of traditional medicine by local populations of their potential. This popular knowledge, considered as an inheritance, can constitute a platform for the exchange of experiences, knowledge, and information concerning the traditional use of medicinal plants.

\section{Acknowledgments}

Thank you for the technical aids, equipment for the forest rangers of the area of Tessala.

\section{Conflict of Interest}

The authors declare that they have no links of interest.

\section{References}

1. Adrar.J ; 2015 Plantes aromatiques et médicinales du Haut Atlas Oriental l'Université d'Errachidia Morocco p4- 61

2. Baba Aissa F 2011, Encyclopédie des plantes utiles. Edition Elmaarifa, 73-269

3. Bachir Bouiadjra. S, El Zerey. W and Khéloufi Benabdeli, 2012 Étude diachronique des changements du couvert végétal dans un écosystème montagneux par télédétection spatiale: cas des monts du Tessala (Algérie occidentale) », Physio-Géo, Volume 5|-1, 211225.

4. Baroudi.M, Benabdeli. K; 2011 Incidence de la fluctuation des précipitations sur l'occupation des sols dans les hautes plaines de Sidi-Bel-Abbès (Algérie) Physeo-géo volume 5./10.4000

5. Belkhadar, J; 1997 La pharmacopée marocaine traditionnelle, médecine arabe ancienne et savoirs populaires Editions le Fennec. Casablanca. 129533.

6. Bellakhdar.J; 2013 Hommes et plantes au Maghreb element pour une méthode en ethnobotanique edition le Fennec.Paris.

7. Dellile L ; 2010 Les plantes médicinales d'Algérie. Édition Berti, 200 p ISBN/EAN : 9789961692028.

8. Dif, M., Benali-Toumi, F., Benyahia, M. et al. 2015 Enquête sur l'utilisation phytothérapique de 11 plantes médicinales poussant dans le Tessala. Phytothérapie 13, 295-297. https://doi.org/10.1007/s10298-015 0962-y

9. Djermouni.N; 2003.100 plantes médicinales d'Algérie. OPU Office des Publications Universitaires, Alger.P100, ISBN: 978.9961.0.0304.6. 
10. Guedira . K, Goetz. P ;2008. les plantes médicinales second Edition Readers Digest Paris p10. ISBN13 987-7098-2020-9

11. Khitri. W, Lardjam.A ; 2018 Plantes antilithiasiques utilisées en médecine traditionnelle dans la ville d'Oran, Algérie Approche ethnobotanique et phytochimique éthnoécologie, 10.4000/ethnoecologie.2511.

12. P. Quezel, S. Santa, 1962, Nouvelle Flore d'Algérie et des régions désertiques méridionales TOME I et II CNRS, Paris France 1170p

13. Paul Ozenda, 1991, Flore et vegetation du Sahra, 3e édition CNRS. 680P ISBN : 2271062306.

14. Rebbas. K 2012 ; Plantes d'intérêt médicinal et écologique dans la région d'Ouanougha (M'Sila, Algérie) Phytothérapie 10:131-142

15. Saad. B, Said.0; 2011 Greco-arab and Islamic Herbal Medicine Traditional system, ethics,Safety efficacy and regulatory issues Wiley edition.

16. Tahri, N., El Basti, A., Zidane, L., Rochdi, A., \& Douira, A. (2012). Etude Ethnobotanique Des Plantes Medicinales Dans La Province De Settat (Maroc). Kastamonu Üniversitesi Orman Fakültesi Dergisi, 12(2), 192-208. 